\title{
The Effect of Financial Literacy and Financial Management Behavior on Retirement Confidence
}

\author{
Dina Patrisia ${ }^{1}$, Moni Fauziah ${ }^{2}$ \\ 1Universitas Negeri Padang, Padang, Indonesia $₫$ patrisiadina@yahoo.com \\ 2Universitas Negeri Padang, Padang, Indonesia $₫$ monifauziah08@gmail.com
}

\begin{abstract}
This research aims to analyze: (1) The effect of financial literacy toward retirement confidence (2) The effect of financial literacy toward financial management behavior (3) The effect of financial management behaviors toward retirement confidence (4) The mediating role of financial management behavior on the relation between financial literacy and retirement confidence. This type of research is causative research. The sample in this research is 200 employees of government and private agencies of Padang Pariaman regencies. This research was Analyzed with Structural Equation Modeling using IBM SPSS Amos 24. The result indicate that: (1) Financial literacy has not a significant effect on retirement confidence (2) Financial literacy has a significant effect on the behavior of financial management (3) Financial management behavior has a significant retirement on confidence (4) Financial management behaviors fully mediated relation between financial literacy and retirement confidence.

Keywords: Financial Literacy, Financial Management Behavior, Retirement Confidence, Mediating
\end{abstract}

\section{Introduction}

Work is an activity by individuals to meet their needs, both physical needs, social and ego needs. Work carried out it could on Government Agencies, private or open their own business (entrepreneurship). Individuals that work well on Government Agencies and Private someday will enter a phase in which he had to stop working because of the aged and no longer productive. But many of the workers were not prepared for the final period of his career thus experiencing all kinds of difficulties after retirement.

Retirement is also a transition period where people need an adjustment to his new status after stopping work. Retirement is an unfortunate state of affairs, not even a little bit negative way society views retirement, assume that workers who have retired are no longer needed in the world of work. This is caused because of old age and productivity has declined to make someone unable to provide benefits to the institution.

Ahead of his retirement people began to worry about the quality of life in old age-related financial and health-care declined, many prospective pension anxious and unprepared for retirement (Kompas.com, 2019). To minimize these conditions would need a good preparation so that the individual has a strong belief in himself to get through retirement. Individuals who have a good understanding in managing finances will certainly have a clear idea of doing the preparation for the future.

Planing in pre-retirement needs to be done properly and carefully to achieve positive retirement confidence. Retirement confidence is a person's attitude and confidence in preparation for [1, 2]. [3] Retirement confidence is a condition where the individual is ready to retire inwardly and outwardly in accordance with the specified time due to the support of several factors that have been prepared beforehand. Retirement confidence is very necessary for the creation of conditions to achieve a safe and comfortable in retirement. [2] confidence a person's retirement can be seen from two things: financial preparation and physical and mental readiness.

The research results of a life insurance company found that the average level of pension spending approximately $94 \%$ of expenditure before retiring. Some expenditure items before retirement, such as education, transport and communications are down. However, expenses relating to housing, health- 
care, food \& beverage increases. In the same survey also found that only $23 \%$ of people in Indonesia who consider retirement planning is an important thing (Kompas, 2017).

From initial observations on 20 labor, labor in which 10 Government Agencies who are civil servants (PNS) and 10 permanent workers Private Agencies Padang Pariaman district. The results of observations show that only $25 \%$ of workers who have the financial confidence, physically and mentally for retirement. While $65 \%$ undecided and $10 \%$ did not have the confidence to face retirement.

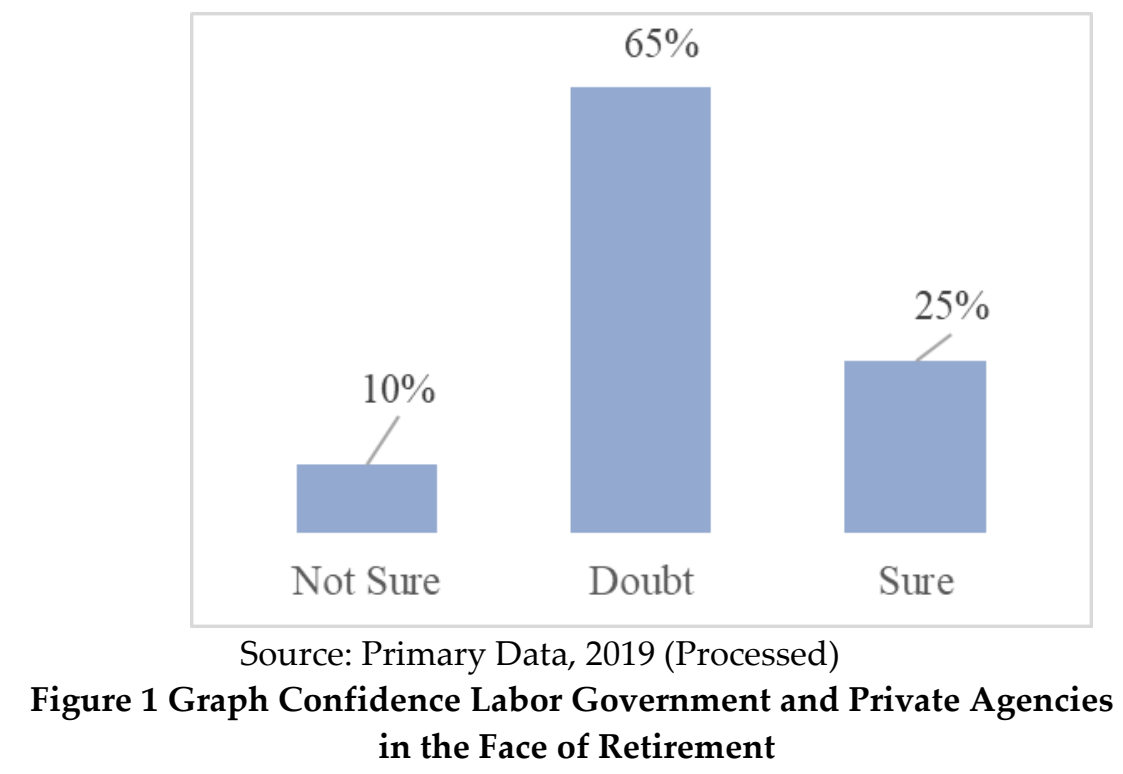

Financial literacy is one of the most frequently cited factor in determining the retirement confidence [1, 4, 5]. [6] Defines financial literacy as financial knowledge and ability to apply it (knowledge and abilities). [2] financial literacy is a skill that can help a person to make financial decisions effectively. Each individual is expected to have knowledge of finance in order to understand more about financial concepts such as interest rates, inflation rates, compound interest, and risk [3].

Financial intelligence is one important aspect of life today because financial literacy is used by individuals for retrieval of financial decisions. Financial literacy is expected to positively correlate to retirement confidence. A basic knowledge of financial management itself has earned by individuals in the learning process in education. But financial literacy Padang Pariaman are still lower than the national end of the financial literacy, where national financial literacy of $29.7 \%$ and financial literacy Padang Pariaman is only $20.3 \%$.

Financial literacy is the knowledge that must be possessed individuals about financial concepts that include basic knowledge of personal finance, savings and borrowing, insurance and investments so that it can take over management of the financial condition in order to be good in the future. Research [2], shows a financial literacy positive effect on retirement confidence.

[7] Show individuals who are financially literate are more likely to have assets other than savings accounts and are more likely to have a fixed deposit accounts, which means that individuals who have good financial literacy will show good financial management behavior anyway. Financial management behavior is a person's ability to regulate: planning, budgeting, audit, management, control, search and storage of everyday financial funds [8]. According to [9], financial management behavior financial responsibility associated with someone about how their financial management. In a study [2] financial management positive effect on retirement confidence. Sound financial management are expected to promote higher pension trust [1].

Then the high financial literacy does not automatically lead to people having a high level of confidence in the pension [5]. Financial literacy can encourage individuals to practice sound financial 
management [10]. Research [5] shows financial literacy will encourage the appropriate use of financial practices, which can increase a person's confidence pension. In this study, researchers also looked at the role of financial management behavior mediates the relationship financial literacy with retirement confidence. In this connection, confirmed the family resource management theory introduced by $[5$, 11]. As proposed by [5, 11], the input (financial literacy) is not sufficient in explaining output (retirement confidence). For this reason, the throughput (the behavior of financial management) should be taken into account to get a better picture of the input-output relationship.

The previous study on retirement confidence has a lot to do, including research conducted [2] examined regarding financial literacy, saving behavior, and retirement confidence in women who work in the public sector of Malaysia [2]. [12] Also examined financial literacy, asset ownership and retirement planning to individuals who have been married in the Netherlands. In research [10] examined the relationship between financial knowledge and financial behavior, which research shows people who have a good financial literacy can affect the financial improvement behavior. In addition [5] conducted a study on financial literacy, financial management practices, and retirement confidence in women who work in government agencies with a model of mediation in financial management practices. But no one has studied the effect of financial literacy and financial management behavior towards retirement confidence, mediation of financial management behavior on financial literacy and retirement confidence in the work force and Private Institutions of Government.

\section{The Effect Financial Literacy on Retirement Confidence}

Have the financial literacy to assist in taking financial decisions responsibly. With their education is one of the factors that make an individual a financial literacy, the better. The more often an individual to get an education so they have a financial literacy will be higher. [1] Suggested that anticipatory socialization affect the way older workers to understand and inteIDRret a pension, and identify the factors of anticipation and preparation for retirement.If seen from the definition of financial literacy proposed by [2] is a financial literacy skills that can help a person to make financial decisions effectively. Where each individual is expected to have knowledge of finance in order to understand more about financial concepts such as interest rates, inflation rates, interest, and risk [3].

In research [12] financial literacy is very closely related to the retirement confidence, that retirement planning is a complex process that requires a level of financial knowledge, there is no doubt that financial literacy and retirement confidence highly correlated. Individuals who have a high level of financial knowledge will better understand the importance of retirement planning and they will amass a fortune as preparation for retirement (Sabri, 2014).

\section{The Effect Financial Literacy on Financial Management Behavior}

Financial literacy refers to what the individual identification of personal financial problems, as measured by levels of knowledge about personal finance concepts [13]). One's knowledge about financial literacy effect on the financial behavior [14]. Financial literacy can make someone use the money wisely, it can also provide benefits to the economy. A person with knowledge of the higher financially able to make better decisions for their families and can improve the economic security and well-being.

Someone with a financial literacy will better understand financial issues as well as better in terms financial behavior. Research conducted by [10] states that a person who has a high financial literacy trends have an influence on a person's financial behavior. This study showed that the literacy rate will affect how people behave towards the decisions taken. And the research found that consumers tend to have the financial literacy over financial management good behavior.

\section{The Effect Financial Management Behavior on Retirement Confidence}

Things were believed people recognize a behavior of the positive and negative aspects, or the tendency to react effectively. Sound financial management are expected to promote higher pension 
trust [15]. Sound financial management should include a variety of financial practices such as cash management, credit management, retirement planning, and estate planning ([10]. People who implement financial management in everyday life tend to show more positive retirement confidence [15].

Financial Management behavior is a person's ability to regulate (planning, budgeting, audit, management, control, search and storage) everyday financial funds [8], For example, people who practice financial management are more likely to save money as a contribution to their pension plan. Financial management practices have helped them become better prepared for retirement and lead to higher pension trust. [2] Financial Management behavior significant positive effect on confidence retirement.

\section{The Mediating Financial Management Behavior on Financial Literacy and Retirement Confidence}

Family Resource Management theory introduced [5, 11] explains how families manage its resources to achieve its objectives. For this reason, the concept of input, throughput, and output is introduced. In summary, the input refers to material resources (money) and human resources (knowledge) owned by the family. As expected, the family will use and utilize the inputs to produce outputs. Output refers to the demand response (satisfaction and confidence) and changes in resources (resources spent).

Based on family resource management theory the relationship between financial literacy and retirement trust questionable. Referring to the "black box" not all individuals who have set the same input with their peers who are illiterate financially alone may not be enough to explain the personal differences in the study of current pension shows the behavior of financial management as a mediator confidence. Individuals will use financial knowledge they (input) to achieve confidence higher pension (output). due to the effect of "black box", not all individuals reach the level of confidence retired high even though they both financial literacy. Therefore, the behavioral level financial management (throughput) is added into relations to explain the irregularities.

Financial literacy will help individuals to learn the importance of financial management as well as the negative consequences of poor financial management, and hence promote the adoption of financial management on a regular basis in daily life [16]. Having determined that financial literacy can lead to behavior better financial management, evidence suggests that the behavior of financial management can have a positive impact on retirement confidence (Kim, Garman, and Quach, 2005a). Theoretically, an individual who consistently applying for retirement finances tend to be more optimistic about their retirement. This is because when people plan for retirement, they will most likely see their retirement goals [5].

Based on the theory and background of the problems noted earlier, it can be made a few hypotheses on the problem as follows:

H1: Financial literacy is positive and significant effect on retirement confidence in the labor of government agencies and private Padang Pariaman.

H2: Financial literacy positive and significant effect on financial management behavior in labor of government agencies and private Padang Pariaman.

H3: Financial management behavior and significant positive effect on retirement confidence in the labor of government agencies and private Padang Pariaman.

H4: Financial management behavior mediates the effect financial literacy and retirement confidence on the labor government agencies and private Padang Pariaman.

\section{Methods}

This type of research is research associations causal. Associative-causal research is a type of research with the characteristics of the problem of causality between two or more variables [17]). In this study tested the hypothesis that has been formulated by distributing a questionnaire, which contains questions structured questionnaire answered by the respondents related to financial literacy, financial management and retirement behavior confidence. 
The population in this study are all labor Government and Private Agencies Padang Pariaman. The research sample is determined with reference to maximum likelihood estimation by [18] with the calculation of 15-20 times the number of parameters estimated. Researchers took 20 times the number of parameters estimates as many as 10, so the total sample of 200 workers.

With the number of samples obtained, based engineering samples used in this study is the method of cluster random sampling where the number of samples taken at each institution in accordance with proportion, ie 100 respondents in the labor force government agencies who are civil servants (PNS) and 100 in the labor and equipment Agencies Private District Padang Pariaman. Operational definition and indicators in this study are described in the following table:

Before performing the necessary research, trials conducted research instrument to see the validity and reliability. based on the validity of test results9 items are statements that are invalid because count $\mathrm{r}<\mathrm{r}$ table is 0.361 . While the reliability test results obtained from research instruments Cronbach's Alpha value of all the variables $>0.6$ indicating that all the variables of the study is reliable.

Table 1 The Operational Definition

\begin{tabular}{|c|c|c|c|c|}
\hline Num. & variables & definition & Indicator & Scale \\
\hline 1. & $\begin{array}{l}\text { Endogenous } \\
(\mathrm{Y}) \\
\text { Retirement } \\
\text { Confidence }\end{array}$ & $\begin{array}{l}\text { State is ready to react and face the } \\
\text { coming period to stop working on a } \\
\text { job that practiced influenced from } \\
\text { within the individual and the } \\
\text { influence of outside individuals [2] }\end{array}$ & $\begin{array}{l}\text { a. Financial readiness } \\
\text { b. Physical and mental } \\
\text { readiness } \\
\text { Source: (Sabri, 2014) }\end{array}$ & Likert \\
\hline 2. & $\begin{array}{l}\text { Exogenous } \\
(X) \\
\text { Financial } \\
\text { Literacy }\end{array}$ & $\begin{array}{l}\text { The series of processes or activities } \\
\text { to improve the knowledge, } \\
\text { confidence and skills of consumers } \\
\text { and the public at large so that they } \\
\text { are able to manage your finances } \\
\text { well [2]. }\end{array}$ & $\begin{array}{l}\text { a. General knowledge } \\
\text { b. Saving and borrowing } \\
\text { c. Insurance } \\
\text { d. Investment } \\
\text { Source: (Chen and } \\
\text { Volpe, 1998; Huston, } \\
\text { 2010; Damanik and } \\
\text { Herdijono, 2016) }\end{array}$ & Likert \\
\hline 3. & $\begin{array}{l}\text { Mediation } \\
(\mathrm{Z}) \\
\text { Financial } \\
\text { Management } \\
\text { behavior }\end{array}$ & $\begin{array}{l}\text { Person's ability to regulate } \\
\text { (planning, budgeting, audit, } \\
\text { management, control, search and } \\
\text { storage) everyday financial funds } \\
\text { [8]. }\end{array}$ & $\begin{array}{l}\text { a. Consumption } \\
\text { b. Cash-Flow } \\
\text { Management } \\
\text { c. Saving and } \\
\text { Investment } \\
\text { d. Credit Management } \\
\text { Source: (Xiao \& Dew, } \\
\text { 2011) }\end{array}$ & Likert \\
\hline
\end{tabular}

Source: Various journals

\section{Results and Discussion}

Respondents in the study were classified by gender, age, education, past, marital status, length of employment and income. Here are the results of research in terms of the characteristics of respondents:

a. The majority of respondents with female sex is, as many as 141 people with 75 people on Government Agencies and 65 people in the Private Agencies.

b. Based on the age dominated by respondents aged 46-50 years in Government Agencies and age less than 30 years in private institutions. 
c. Based on recent education is dominated by the respondents to the latest educational and SI on Government Agencies on Agencies Private High School.

d. The majority of respondents to the married marital status is, as many as 179 people where 89 people in Government Agencies and 90 at private institutions.

e. Based on the working lives are dominated by the respondents with a work period of 10-15 years, as many as 68 people of which 38 people in Government Agencies and 30 people in the Private Agencies.

f. Based on revenue by respondents with income IDR 2,500,000 to IDR 3,500,000 ie 51 governance agencies and 43 people at a private institution.

Table 2 Characteristics of Respondents

\begin{tabular}{|c|c|c|c|c|c|c|}
\hline & \multicolumn{2}{|c|}{$\begin{array}{c}\text { GOVERNMENT } \\
\text { AGENCIES }\end{array}$} & \multicolumn{2}{|c|}{$\begin{array}{c}\text { PRIVATE } \\
\text { AGENCIES }\end{array}$} & \multirow[t]{2}{*}{ TOTAL } & \multirow[t]{2}{*}{$\%$} \\
\hline & Fi & $\%$ & $\mathrm{Fi}$ & $\%$ & & \\
\hline \multicolumn{7}{|l|}{ GENDER } \\
\hline WOMAN & 76 & 76 & 65 & 65 & 141 & 70 \\
\hline MAN & 24 & 24 & 35 & 35 & 59 & 30 \\
\hline TOTAL & 100 & & 100 & & 200 & \\
\hline \multicolumn{7}{|l|}{ AGE } \\
\hline$<30$ & 14 & 14 & 27 & 27 & 41 & 20 \\
\hline $30-35$ & 15 & 15 & 21 & 21 & 36 & 18 \\
\hline $36-40$ & 19 & 15 & 15 & 15 & 34 & 17 \\
\hline $41-45$ & 19 & 19 & 16 & 16 & 35 & 18 \\
\hline $46-50$ & 22 & 22 & 16 & 16 & 38 & 19 \\
\hline$>50$ & 11 & 11 & 5 & 5 & 16 & 8 \\
\hline TOTAL & 100 & & 100 & & 200 & \\
\hline \multicolumn{7}{|l|}{ MARITAL STATUS } \\
\hline SINGLE & 11 & 11 & 10 & 10 & 21 & 11 \\
\hline MARRIED & 89 & 89 & 90 & 90 & 179 & 89 \\
\hline TOTAL & 100 & & 100 & & 200 & \\
\hline \multicolumn{7}{|l|}{ YEARS OF SERVICE } \\
\hline$>30$ & 2 & 2 & 0 & 0 & 2 & 1 \\
\hline $26-30$ & 4 & 4 & 0 & 0 & 4 & 2 \\
\hline $21-25$ & 6 & 6 & 13 & 13 & 19 & 10 \\
\hline $16-20$ & 21 & 21 & 13 & 13 & 34 & 17 \\
\hline $10-15$ & 38 & 38 & 30 & 30 & 68 & 34 \\
\hline$<10$ & 29 & 29 & 44 & 44 & 73 & 36 \\
\hline TOTAL & 100 & & 100 & & 200 & \\
\hline \multicolumn{7}{|l|}{ INCOME } \\
\hline$<$ IDR1,500,000 & 0 & 0 & 7 & 7 & 7 & 4 \\
\hline IDR1,500,000 - IDR2,400,000 & 11 & 11 & 32 & 32 & 43 & 21 \\
\hline IDR2,500,000 - IDR3,500,000 & 51 & 51 & 43 & 43 & 94 & 47 \\
\hline$>$ IDR $3,500,000$ & 38 & 38 & 18 & 18 & 56 & 28 \\
\hline
\end{tabular}

Source: Primary Data, 2019 (Processed)

\section{Test Assumptions Structural Equation Modeling (SEM)}

Before the data were analyzed, first tested the assumption of SEM consists of outlier test, normality test, and test multimillionaires. Mahalanobis outlier test detected by distance. The criteria used is based on the value of chi-squares in the degrees of freedom (degree of freedom) 10 is the 
number of indicator variables on a significant level of $\mathrm{p}<0.001$. Value mahalanobis distance X2 (10; $0.001)=29.588$. This means that all the cases that have a greater distance mahalanobis 29.588 is multivariate outliers. Based on the results mahalanobis distance output from IBM SPSS AMOS program 24 obtained the highest grades mahalanobis 22.164, thus there are no symptoms of an outlier because the highest mahalanobis smaller than the value chi-squares $(22.164<29.588)$.

Test normality of the data by looking at the output ofassessment of normality. Normality test is done using criteria critical ratio value equal skewness $\leq 2.58$ at 0.01 the significance level, From the data analysis, the critical ratio value of skewness value of all the indicators show normal distribution because of its value under 2:58. The multivariate normality test value $\mathrm{cr} 0.141<2.58$. So multivariate normally distributed data. IBM SPSS output results AMOS 24 value determinant of the sample covariance matrix $=0000$. From the output of the calculation results determinant of the sample covariance matrix can know the value of the sample covariance matrix determinant is close to zero. Thus it can be said that the research data used are multikolinearitas however unacceptable because the requirements are met assuming another SEM [19].

\section{Analysis of Structural Equation Modeling (SEM) \\ Measurement Model Test}

Measurement models tested by Confirmatory Factor Analysis (CFA). The puIDRose of measurement is to measure how far the model size indicator latent constructs capable of reflecting the theoretical, with the proviso significancep, value $<0.05$. Based on the data processing that has been done shows that all indicators generate value $\mathrm{p}$ under 0.05 . This can be explained that the data from the results of the questionnaire areinvalid, Furthermore, based on the reliability testing done shows that all constructs are measured realibel.

\section{Multigroup Analysis}

[20] Goal Multigroup analysis is done to see if kompenen measurement model and structural model of equal (invariant) for the two sample groups in Government and Private Agencies. The following Table 3 presents a comparison of the value of chi-square model of the fourth unconstraint with the baseline model.

Table 3 Goodness-Fit Test Statistics for Multigroup Invariance

\begin{tabular}{ccccccc}
\hline Number & Model & X2 & Df & $\mathbf{\Delta X 2}$ & $\mathbf{\Delta d f}$ & Sig \\
\hline 1 & unconstrained & 366628 & 64 & - & - & - \\
\hline 2 & measurement of weight & 409494 & 71 & 42866 & 7 & $\mathbf{P}<\mathbf{0 . 0 5}$ \\
\hline 3 & structural covariances & 436135 & 75 & 69507 & 11 & $\mathbf{P}<\mathbf{0 . 0 5}$ \\
\hline 4 & structural residual & 437028 & 77 & 70400 & 13 & $\mathbf{P}<\mathbf{0 . 0 5}$ \\
\hline $\mathbf{5}$ & measurement of residual & 528459 & 87 & 161831 & 23 & $\mathbf{P}<\mathbf{0 . 0 5}$ \\
\hline
\end{tabular}

Source: Data on Calculation Result Using IBM SPSS AMOS 24

Based on Table 3 note that the views from the measurement model (measurement of weight) two sample groups in Government and Private Agencies in contrast to the 5\% significance level. So to test structural models on Government and Private Agencies different.

\section{Structural Model Test}

Based on Figure 2 below R-square or retirement SMC confidence on Government Agencies is 0.750. This means that $75 \%$ of the labor retirement confidence on Government Agencies affected by the financial literacy and financial management behavior, while the remaining $25 \%$ is influenced by other variables that are not described in this study. 


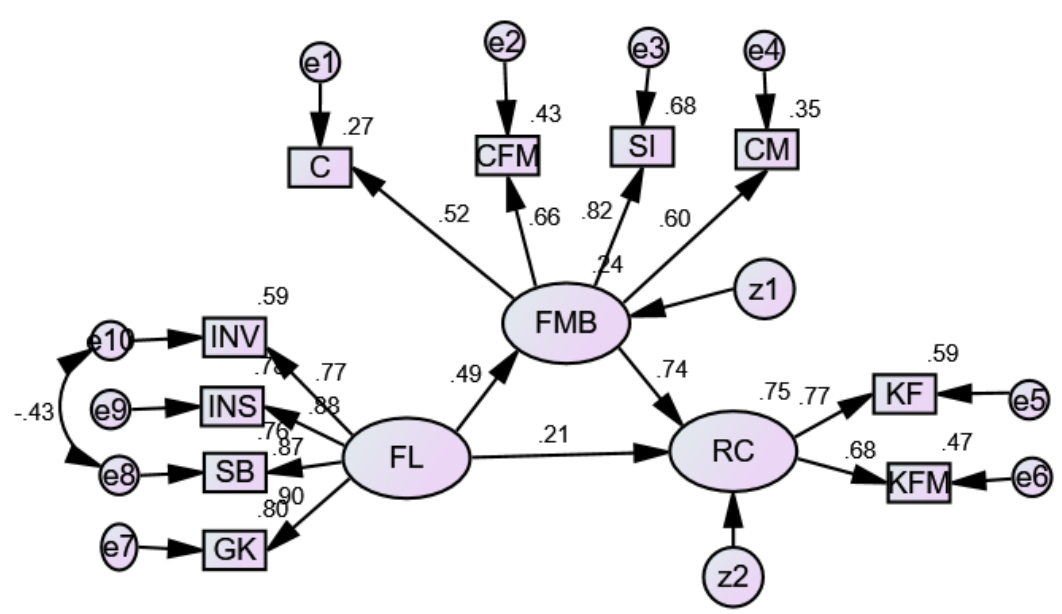

Squared Multiple Correlation (SMC) for Retirement Confidence: 0.750

Figure 2 Structural Model Working Tanaga Government Agencies

Figure 3 shows a structural model of labor tanaga Private Agencies R-square or retirement SMC confidence in private institutions are 0.109 . This means $11 \%$ confidence retirement employment in private institutions affected by the financial literacy and financial management behavior. While the remaining $89 \%$ is influenced by other variables that are not described in this study. It can be concluded the influence of financial literacy and financial management of the retirement behavior of confidence on Government Agencies workforce larger than private agencies.

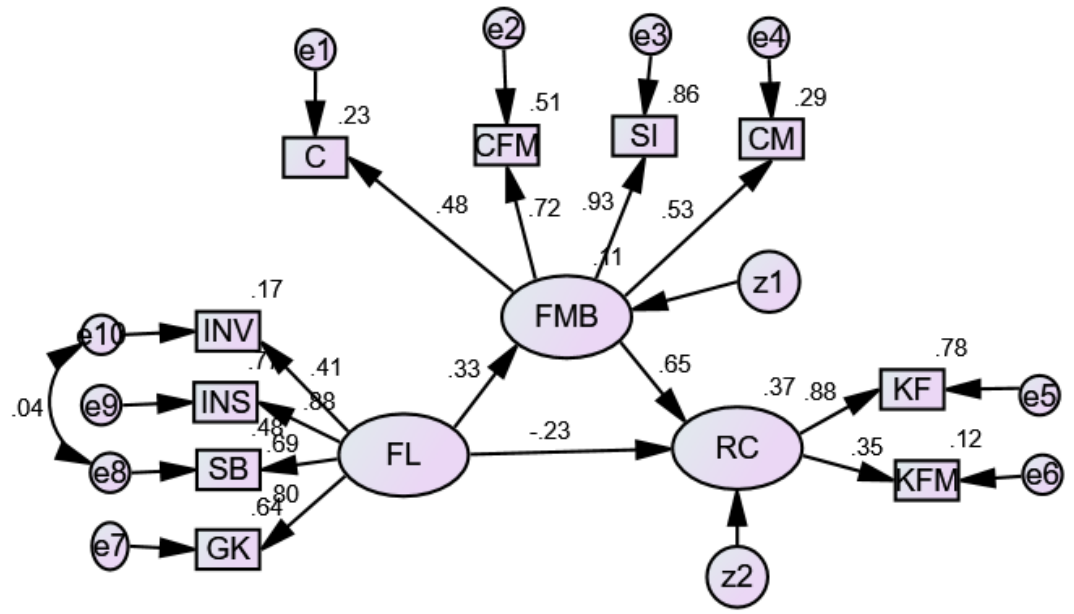

Squared Multiple Correlation (SMC) for Retirement Confidence: 0.109

Figure 3 Structural Model Tanaga Private Employment Agencies

\section{Hypothesis Testing}

Table 4 Regression Weights Government Agencies

\begin{tabular}{|c|c|c|c|c|c|c|c|}
\hline \multicolumn{4}{|c|}{ Hypothesis } & Std. Estimate & $\mathrm{Cr}$ & $\mathbf{P}$ & Result \\
\hline \multicolumn{8}{|c|}{ Government agencies } \\
\hline 1 & $\mathrm{RC}$ & $<---$ & FL & .213 & 1,830 & .067 & Not significant \\
\hline 2 & FMB & $<---$ & FL & .490 & 3,546 & .000 & Significant \\
\hline 3 & $\mathrm{RC}$ & $<---$ & FMB & .741 & 3,984 & .000 & Significant \\
\hline \multicolumn{8}{|c|}{ Private agencies } \\
\hline 1 & $\mathrm{RC}$ & $<---$ & FL & -.227 & -1950 & .051 & Not significant \\
\hline 2 & FMB & $<---$ & FL & .330 & 2524 & .012 & Significant \\
\hline 3 & $\mathrm{RC}$ & $<---$ & FMB & .648 & 3858 & .000 & Significant \\
\hline
\end{tabular}


Table 5 Standardized Effects

\begin{tabular}{|c|c|c|c|c|c|c|}
\hline \multicolumn{4}{|c|}{ Hypothesis } & Total Effect & Direct Effect & Indirect Effect \\
\hline \multicolumn{7}{|c|}{ Government agencies } \\
\hline 4 & $\mathrm{RC}$ & $<-$ & FL & .576 & .213 & .363 \\
\hline \multicolumn{7}{|c|}{ Private agencies } \\
\hline 4 & $\mathrm{RC}$ & $<-$ & FL & -.013 & -.227 & .214 \\
\hline
\end{tabular}

The first hypothesis in this study is a financial literacy significant positive effect on the labor retirement confidence in Government and Private Agencies Kab. Padang Pariaman. For financial literacy in the Public Authorities obtained the value of $1.83 \mathrm{cr} p \leq 0.067 \geq 1.96$ and 0.05 and a financial literacy in Private Institutions 1.95 cr values obtained $p \leq 0.051 \geq 1.96$ and 0.05 of this case shows that financial literacy variables did not significantly affect retirement variable workforce confidence in Government and Private Agencies Kab. Padang Pariaman. Thus, the first hypothesis is rejected.

The second hypothesis in this study is a financial literacy significant positive effect on financial management in labor behavior Government Agencies and Private Kab. Padang Pariaman. For Public Authorities obtained a financial literacy cr value $\geq 3.5460 .000 \mathrm{p} \leq 1.96$ and 0.05 and a financial literacy Private Agencies cr values obtained $2.5240 .012 \geq 1.96$ and $\mathrm{p} \leq 0.05$, it indicates that the variables significantly influence financial literacy to the financial variables on labor management behavior Government Agencies and Private Kab. Padang Pariaman. Thus, the second hypothesis is accepted. In Table 4 Agencies pemerintaha viewable financial literacy behaviors affect financial management amounted to 0.490, while the Private Institution of 0.330, it can be concluded labor Kab government agencies. Padang Pariaman applying greater financial literacy held on the behavior of financial management.

The third hypothesis in this study is the behavior of financial management significant positive effect on the labor retirement confidence in Government and Private Agencies Kab. Padang Pariaman. For Public Authorities obtained a financial literacy cr value $\geq 3.9840 .000 \mathrm{p} \leq 1.96$ and 0.05 and a financial literacy private individual agency get value $\mathrm{cr} \geq 3.8580 .000 \mathrm{p} \leq 1.96$ and 0.05 , it indicates that the financial variables affect behavior management significant to variable labor retirement confidence in Government and Private Agencies Kab. Padang Pariaman. Thus the third hypothesis accepted. Table 4 Government Agencies viewable financial management affect retirement behavior of 0.741 whereas confidence in Private Institutions of 0.648 , it can be concluded labor Kab government agencies. Padang Pariaman more memeiliki retirement confidence better than private institutions having to apply sound financial management behavior, both in terms of consumption, cash flow management, savings and investment and credit Risk Management.

The fourth hypothesis in this study is the financial management of a financial literacy behavior mediates the relationship with the labor retirement confidence in Government and Private Agencies Kab. Padang Pariaman. From Table regression weights and standardized effect known that the direct effect of a financial literacy to retiriment confidence Government Agencies amounted to 0.213 smaller than the indirect effect (indirect effect) which is worth 0,363 , and at agencies Private direct influence financial literacy to the retirement confidence of -, 221 more smaller than the indirect effect (indirect effect) which is worth 0.214 .

\section{The Effect Financial Literacy on Retirement Confidence}

Based on the results of hypothesis testing showed that financial literacy does not significantly influence the labor retirement confidence in Government and Private Agencies Kab. Padang Pariaman. This shows that financial literacy as a basic knowledge of finance, savings and loans, insurance and investments owned by workers in Government and Private Agencies Padang Pariaman district does not directly influence pensiunya confidence. 
These results are very different from previous research [12]financial literacy is closely related to retirement confidence. Research [2]stated Individuals who have a high level of financial knowledge will better understand the importance of retirement planning and they will accumulate wealth in preparation for retirement.

The different results in this study with previous research related to the realization of financial literacy held in everyday life, when labor does not apply financial knowledge possessed in everyday life as in managing consumption, cash flow management, savings and investment, and management credit then it will not have an impact on the confidence of labor pension. So we can conclude high or low financial literacy (financial literacy) owned labor can not directly affect the confidence pension (retirement confidence) labor.

\section{The Effect Financial Literacy on Financial Management Behavior}

Based on the hypothesis of a financial literacy test results have a significant positive influence on the financial management of labor behavior in Government and Private Agencies Kab. Padang Pariaman. This shows that financial literacy is owned by the workers and the Government Agencies Private Padang Pariaman affect the behavior of the financial management of labor both in making consumption, cash flow management, savings and investment, and credit management.Financial literacy workers are able to make use money wisely, it can also provide benefits to the economy.

Agencies pemerintaha on financial literacy behaviors affect financial management amounted to 0.490, while the Private Institution of 0.330 , it can be concluded labor Kab government agencies. Padang Pariaman applying greater financial literacy held on the behavior of financial management. Good financial literacycan make someone use the money wisely, it can also provide benefits to the economy. Someone with a higher financial knowledge are able to make better decisions for their families and can improve the economic security and well-being meraka.

The results are consistent with previous research conducted [10]) states that a person who has a high financial literacy trends have an influence on a person's financial behavior. [21]states, someone with a good knowledge of finance will have a more responsible financial behavior. Research $[9,22]$ states, there is the influence of the financial management of a financial literacy behavior,

\section{The Effect Financial Management Behavior on Retirement Confidence}

Based on the results of financial management behaviors significant positive effect on the labor retirement confidence in Government and Private Agencies Kab. Padang Pariaman. This suggests that the behavior of financial management workforce Government Agencies and Private Padang Pariaman affects the confidence of labor pension. Workers who perform good financial management of the consumption, cash flow management, savings and investment, and credit management will produce a strong belief because pensions have to prepare for retirement.

Based on the results of financial management behavior has a higher standard estimate of the other variables, so that the behavior of financial management is a major factor for the workforce to be able to form a strong pension confidence. In Table 4 Government Agencies viewable financial management affect retirement behavior of 0.741 whereas confidence of Private Institutions of 0.648 , it can be concluded labor Kab government agencies. Padang Pariaman more memeiliki retirement confidence better than private institutions having to apply sound financial management behavior, both in terms of consumption, cash flow management, savings and investment and credit Risk Management.

The results are consistent with previous research [2] financial management is the most significant predictor of trust in pensions compared with other variables. [2] Suggests that people will have confidence that high pension when they actively participate in financial management, such as retirement planning. Active involvement in the plan will produce a strong belief towards their retirement. 
The Mediating Financial Management Behavior on Financial Literacy and Retirement Confidence

Based on the results of financial management behaviors mediate the association financial literacy with confidence on the labor retirement Government Agencies and Private Kab. Padang Pariaman. This suggeststhat the impact of financial literacy on retirement belief is indirect and mediated by the behavior of financial management. In other words, increasing the financial literacy of labor Government and Private Agencies will encourage workers to menapilkan behavior better financial management, which will further improve pension confidence as well. As suggested by [10], a low financial literacy is a powerful obstacle to display the proper financial management behavior. Financial literacy is very important to make effective financial decisions [5]. As a consequence of the behavior of proper financial management, the individual will have a strong conviction to retire.

In this connection, confirmed the family resource management theory introduced by Deacon and Firebaugh (1988). As proposed by [5, 11], the input (financial literacy) is not sufficient in explaining output (confidence pension). For this reason, the throughput (financial management practices) should be taken into account to get a better picture of the input-output relationship. And the results of this study in accordance with previous studies [5]financial management mediates the relationship behavior with retirement financial literacy confidence.

\section{Conclusion}

Based on the results of research and discussion that has been done can be summarized as follows: (1) Financial literacy is no significant effect on retirement confidenceon labor and Private District Government Agencies. Padang Pariaman. (2) Financial literacy significantly influence the behavior of financial management on labor and Private District Government Agencies. Padang Pariaman. (3) Financial management behavior significant effect on retirement confidenceon labor and Private District Government Agencies. Padang Pariaman. (4) Financial management behavior mediate relations with retirement financial literacy confidence on labor and Private District Government Agencies. Padang Pariaman.

Based on the research results, increasing confidence that a good retirement, the labor force can participate in the pre-retirement counseling, coaching, and counseling for retirement to be more prepared and confident for retirement. Suggested workforce to better maintain their consumption levels by means of a higher priority to the needs not wants. Then labor must either scale mebuat weekly budget and moon, this is done so that expenditure can be controlled and do not exceed the budget. Disaran labor to begin storage and pengahasilan obtained investment from both short-term and long-term such as retirement. It can mebantu financial preparation for retirement later. For the agency may increase pre-retirement counseling, coaching, and counseling for its workforce retirement. For the next researcher can develop research by adding a few other variables that may affect pension beliefs. And conduct research in areas with a broader scope to produce better research.

This study has limitations, among others, this study only focused on Pegewai Civil Institutions of Government and Private Agencies labor Padang Pariaman district. The author also restrict the research variables, which only use a variable financial literacy, financial management behavior, and retirement confidence.

\section{References}

Al Kholilah, N., and Iramani, R.: 'Studi Financial Management Behavior pada Masyarakat Surabaya', Journal of Business \& Banking, 2013, 3, (1), pp. 69-80

Bahri, S., and Zamzam, F.: 'Model penelitian kuantitatif berbasis SEM-Amos', Yogyakarta: Deepublish, 2014

Deacon, R.E., and Firebaugh, F.M.: 'Family resource management: Principles and applications' (Allyn \& Bacon, 1988. 1988)

Ferdinand, A.: 'Structural equation modeling dalam penelitian manajemen', Semarang: Badan Penerbit Universitas Diponegoro, 2002 
Ghozali, I.: 'Model persamaan struktural konsep dan aplikasi dengan program AMOS 22.0 update bayesian SEM', Semarang: Badan Penerbit Universitas Diponegoro, 2014.

Grable, J.E., Park, J.Y., and Joo, S.H.: 'Explaining financial management behavior for Koreans living in the United States', Journal of Consumer Affairs, 2009, 43, (1), pp. 80-107.

Grohmann, A.: 'Financial literacy and financial behavior: Evidence from the emerging Asian middle class', Pacific-Basin Finance Journal, 2018, 48, pp. 129-143

Huston, S.J.: 'Measuring financial literacy', Journal of Consumer Affairs, 2010, 44, (2), pp. 296-316

Hilgert, M.A., Hogarth, J.M., and Beverly, S.G.: 'Household financial management: The connection between knowledge and behavior', Fed. Res. Bull., 2003, 89, pp. 309

Ida, I., and Dwinta, C.Y.: 'Pengaruh Locus of Control, financial knowledge, income terhadap financial management behavior', Jurnal Bisnis dan Akuntansi, 2010, 12, (3), pp. 131-144

Kim, J., Garman, E.T., and Quach, A.: 'Workplace financial education participation and retirement savings by employees and their spouses', Journal of Personal Finance, 2005, 4, (3), pp. 92-108

Kim, J., Kwon, J., and Anderson, E.A.: 'Factors related to retirement confidence: Retirement preparation and workplace financial education', Financial Counseling and Planning, 2005, 16, (2), pp. 77-89

Lusardi, A., and Mitchell, O.S.: 'Planning and financial literacy: how do women fare?', American Economic Review, 2008, 98, (2), pp. 413-417

Lusardi, A., and Mitchell, O.S.: 'The economic importance of financial literacy: Theory and evidence', Journal of economic literature, 2014, 52, (1), pp. 5-44

Marsh, B.A.: 'Examining the personal finance attitudes, behaviors, and knowledge levels of first-year and senior students at Baptist universities in the state of Texas', Bowling Green State University, 2006

Nyamute, W., and Maina, J.: 'Effect of financial literacy on personal financial management practices: A case study of employees of finance and banking institutions', University of Nairobi Electronic Repository,[online] http://erepository. uonbi. ac. ke, 2011, 8080

Perry, V.G., and Morris, M.D.: 'Who is in control? The role of self-perception, knowledge, and income in explaining consumer financial Behavior', Journal of Consumer Affairs, 2005, 39, (2), pp. 299-313

Sabri, M.F., and Juen, T.T.: 'The influence of financial literacy, saving behaviour, and financial management on retirement confidence among women working in the Malaysian public sector', Asian Social Science, 2014, 10, (14), pp. 40

Sabri, M.F., Juen, T.T., Othman, M.A., and Rahim, H.A.: 'Financial literacy, financial Management practices, and retirement confidence among Women working in government Agencies: A mediation model', The Journal of Developing Areas, 2015, 49, (6), pp. 405-412

Sabri, M.F., MacDonald, M., Masud, J., Paim, L., Hira, T., and Othman, M.: 'Financial behavior and problems among college students in Malaysia: Research and education implication', Consumer Interests Annual, 2008, 54, (1), pp. 166-170

Sugiyono, P.: 'Metode penelitian kombinasi (mixed methods)' (Alfabeta, 2015. 2015)

Van Rooij, M.C., Lusardi, A., and Alessie, R.J.: 'Financial literacy and retirement planning in the Netherlands', Journal of Economic Psychology, 2011, 32, (4), pp. 593-608 